\title{
Do Investors Still Gravitate to Preferred Habitats on the US Treasury Yield Curve?
}

\author{
Kenneth S. Dreifus (Corresponding author) \\ Department of Business and Accounting, Touro College, NY, USA \\ Tel: 212-463-0400 x 5425 E-mail: Kenneth.Dreifus@touro.edu
}

\begin{abstract}
Angelo DeCandia
Department of Business and Accounting, Touro College, NY, USA

E-mail: Angelo.DeCandia@touro.edu

Elliot Goldberg

Department of Business and Accounting, Touro College, NY, USA

E-mail: Eliezer.Goldberg2@touro.edu
\end{abstract}

\author{
Mohammed S. Chowdhury \\ Department of Business and Accounting, Touro College, New York, NY, USA \\ E-mail: Mohammed.Chowdhury@touro.edu
}

Received: March 21, 2018 Accepted: April 10, 2018 Published: May 26, 2018

doi:10.5296/ber.v8i2.12861 URL: https://doi.org/10.5296/ber.v8i2.12861

\begin{abstract}
The purpose of this study is to test the preferred habitat theory non-econometrically using interviews with the help of a questionnaire for self-guidance on a group of focused investors. Frequencies and simple percentages were used to analyze data. Though many generations of post-World War II economics and finance students were taught that the nature of the liabilities on the balance sheet and the desire to avoid mismatches against assets caused particular classes of investors to gravitate to a preferred habitat on the yield curve, our study based on the responses to questionnaires by a group of U.S. based bond traders and risk
\end{abstract}


analysts shows that more than half of the respondents have no preference as to where on the curve they trade, whether the trade is on behalf of their customers or for the house, and that their arbitrage strategies are driven by opportunities for profit.

Keywords: Arbitrage, Preferred habitat, Keynes theory of liquidity premium, Securities, Yield curve, Non-econometric test

\section{Introduction}

The Preferred Habitat Theory (known as PHT in this paper) proposed in the mid-1960s by Franco Modigliani and Richard Sutch, states that individual investors have a preferred range of bond maturity lengths, and will only go outside of this range if a higher yield is promised. This theory also states that investors prefer shorter-term bonds to long-term bonds and the yields on long- term bonds should be higher than shorter-term bonds. Therefore, PHT thus plays a crucial role in the determination of bond yields and relative supply of long-term bonds. The strength of the positive relationship depends on the risk aversion of arbitrageurs that participate in the bond market. PHT hypothesis is confirmed if individual investors have a preferred range of bond maturity lengths, and will go outside of this range only if a higher yield is promised.

Even though many generations of post-World War II economics and finance students were taught that the nature of the liabilities on the balance sheet and the desire to avoid mismatches against assets caused bond investors to gravitate to a preferred habitat on the yield curve, it has never gained a wide-spread acceptance among academia and non-academia (practitioners), likely for the existence of alternative theories of non-arbitrage models known that expounded the expectations hypothesis (EH). The conflict of PHT with the logic EH is discussed in the financial literature (Cox, Ingersoll, \& Ross, 1985).

The pursuit of this research is motivated by the realization that large international banks and central banks have trading desks staffed by well-compensated, astute individuals who trade bonds, and that their ability to arbitrage is at present heavily restricted by the flat nature of the yield curve. If the traditional theory was true, then trading and arbitrage activities would all occur in the habitat appropriate to that particular institution - commercial banks at the short-end of the curve to match the bulk of their short liabilities (largely customer deposits), and insurance companies and pension plans on the long end, reflecting the fact that many of the claims on them will be made 30 years or more from now.

Bond investors care about both maturity and return. The theory suggests that short-term yields will almost always be lower than long-term yields due to an added premium needed to entice bond investors to purchase not only longer term bonds, but bonds outside of their maturity preference. Economic theory tells us that monetary policy may have a direct effect on short-term rates, but little or no direct effect on longer-term rates (Hyoung-Seok, 2005) . The returns to maturity are determined by the demand for and supply of bonds in each maturity. So, there is no reason to assume that longer-term bonds always pay a higher premium than shorter-term ones (Elton, Brown, \& Goetzman, 2003). But the 2008 financial crisis brought about strong demand for government bonds as investors looked for safe havens. 
During this time of recession and financial bailout, the government's substantial increase in borrowing generated large upward pressure on rates causing decreases in bond value. In this unstable financial market, the Dodd-Frank Wall Street Reform Act became law to regulate the financial markets, raising the issue to determine if there was a change in the investors' preferred habitats for bond trades.

\section{Research Questions}

Therefore, the questions that arise in this study are:

- Do investors still tend to trade on the PHT yield curve?

- Do investors have a preferred maturity (short-term over the long-term and vice versa) on the yield curve when using a buy or hold strategy?

- Do investors have a preferred maturity on the yield curve when they trade in and out of treasuries?

- Do investors believe that government legislation like the Dodd-Frank Act causes changes in their trading practices?

- Do investors believe that they have preferred habitats for arbitrage?

By answering the questions raised in this study, we hope to develop a better understanding of whether investors' behavior is consistent with Preferred Habitat Theory. Although econometric modeling has been the favorite method among economists, there have been few efforts at modeling causal sequences. This study is designed to examine the impact of PHT on the yield curves when the yield curve is essentially flat. The paper adds to the financial literature since large-scale surveys to look at the effects of PHT on the yield curve have not yet been widely researched and validated.

Based on the research questions raised in this study we draw the following hypotheses in null form.

\section{Hypotheses in Null Form}

a. Investors do not have a maturity preference on the yield curve when using a buy and hold strategy.

b. Investors do not have a maturity preference when they trade in and out of the Treasuries.

c. Investors do not tend to engage in arbitrage only in their preferred habitat for higher return.

d. Investors do not tend to consider preferred habitat when using a buy and hold strategy.

e. Investors do not tend to change their trading practices if there is a government legislation to regulate the market.

\section{Justification of the Study}

First: In economics and financial literature, the theories of term structure of interest rates have been very important subjects to economists, financial analysts and academia. Second: PHT is an evolving theory since it is an extension of two other theories (market segmentation theory and expectation theory). Finally: As spreads have shrunk drastically since the 
beginning of the Quantitative Easing program instituted by the Fed at the beginning of the Great Recession, and term premia have all but disappeared, it certainly raises the question as to whether the hoary beliefs first annunciated more than a half-century ago are still valid in a time of huge volumes, low yields, minuscule spreads, and computer-assisted 24/7 equities trading.

\section{Literature Review}

The PHT theory postulates that different bond investors prefer one maturity length over another and are only willing to buy bonds outside of their maturity preference if offered sufficient premia. It is a variation of the expectation theory and an extension of market segmentation theory. All these theories were directed toward explaining the shape of yield curve. Let us look first at expectation theory and market segmentation theory to get a meaningful picture of the preferred habitat of the investors.

\subsection{Expectation Theory (EH)}

Muth (Muth, 1961) developed the notion that investors of bonds do not prefer bonds of one maturity over another, so they will not hold any bond if its expected return is less than that of another bond with a different maturity. But the theory has been shown to be inaccurate in execution, because interest rates typically do not stay flat when the yield curve is normal. That means investors have no particular preference when it comes to different maturities and the risks associated with them.

\subsection{Liquidity Preferences (LP)}

John Maynard Keynes (Keynes, 1936) was the first to introduce the liquidity preference theory in Chapter 13 of his opus The General Theory of Employment, Interest and Money. The theory states that investors are primarily interested in purchasing short-term securities to reduce interest rate risks. It means investors would demand a liquidity premium for holding bonds for longer term with a bias toward a positively sloped yield curve. Liquidity premiums failed to provide a clear intuition for some features of the yield curve. In so far as the premium should always be high and positive, this approach would undermine the ability of the model to replicate.

\subsection{Market Segmentation Theory (MST)}

The Market Segmentation Theory tries to describe the relation of the yield of a debt instrument with its maturity period. This theory states that the market for different-maturity bonds is completely separate and segmented. The interest rate for a bond with a given maturity is determined by the supply and demand for bonds in that segment with no effect from the returns on bonds in other segments. Market demand and supply will determine the shape of yield curve. If the demand by short term investors is very high, the yield curve will steepen and vice versa. The defect of this this theory is that it overlooks the fact that there is a considerable degree of overlapping between different markets. Some institutions operate in several markets dealing in securities of different maturities. 


\subsection{Preferred Habitat Theory (PHT)}

PHT is an extension of the market-segmentation theory of Culbertson (Culbertson, 1957). The essence of the theory is that investors would operate within their preferred habitat, and would operate outside their preferred habitat only if they are sufficiently compensated through higher returns. It means that they desire long-term securities over short -term securities only if a higher return is promised. This could even cause higher yields for short-term securities over the long-term-securities if the majority of the buyers were those who preferred to hold long-term bonds.

The PHT on the yield curve was first discussed by Modigliani and Sutch (Modigliani \& Sutch, 1966). They argued that the buyers of bonds are heterogeneous in their desires, and that they would pay a premium (and accept a lower yield) to get the maturity that they wanted. This explanation would account for the flattening of the upward sloping shape of the curve under expansive economic conditions. The implication was discouraging, as the composition of federal debt would have had little or no effect on the short-long rate spread. This insight from Modigliani and Sutch generated additional PHT research and gained prominence with the advent of the Great Recession that affected the entire globe.

Since then, the contributions of Vayanos \& Vila (Vayanos and Vila 2009) and Krishnamurthy \& Vissing-Jorgensen (Krishnamurthy \& Vissing-Jorgensen, 2012) have provided updated theoretical frameworks of PHT. Empirical tests such as those of Greenwood \& Vayanos (Greenwood \& Vayanos, 2010) and Guibaud, Nosbusch \& Vayanos (Guibaud, Nosbusch, \& Vayanos, 2013) have mostly sought to find evidence of market dynamics consistent with PHT from the bond supply side.

Krishnamurthy and Vissing-Jorgensen op. cit. find a strong negative correlation between credit spreads and the Debt-to-GDP ratio, and argue that this reflects a downward-sloping demand for government bonds. Greenwood and Vayanos op. cit. find that the average maturity of government debt predicts positively excess bond returns, a result they also derive theoretically within their model. Guibaud, Nosbusch and Vayanos op.cit. show that catering to maturity clienteles is an optimal issuance policy: a welfare-maximizing government issues more long-term debt when the fraction of long-relative to short-horizon investors increases. Greenwood, Hanson and Stein (Greenwood, Hanson and Stein, 2010) find that corporations engage in gap-filling behavior, issuing long-term debt at times when the supply of long-term government debt is small.

Other studies further buttressed the widespread belief in PHT. Kuttner (Kuttner, 2006) presented econometric evidence showing that changes in the Fed's portfolio of long-term securities had statistically significant and measurable effects on premia associated with Treasury ("T")-notes in the two to five years maturity range. Vayanos and Vila op.cit. built a model to explore the interaction between investor clients and arbitrageurs that relates yields to demand. Riedel (Riedel, 2010) published a mathematical proof positing that heterogeneous agents (traders with different preferences) facilitate the creation of a yield curve that is shaped according to PHT. Greenwood and Vayanos op.cit. acknowledged that changes in clientele demand and bond supply are also important drivers to term structure. Ellison and 
Tischbirek (Ellison \& Tischbirek, 2014) looked at unconventional government debt purchases as exemplified by Operation Twist and QE I-II, and expounded the idea that supply side issues (bond availabilities) do have an impact on rates through PHT, as investors regard T-bonds of different maturities as imperfect substitutes, and are willing to pay a premium to get the maturities they really want. Two contemporary papers, one by Albuquerque (Albuquerque, 2017) and the other by Gorodnichenko and Ray (Gorodnickenko \& Ray, 2017) concluded, albeit from different directions, additional support for PHT. PHT became popular as a plausible rationale for term premiums which are not restricted in sign or monotonicity, rather than as a necessary causal explanation.

The important work of these researchers undoubtedly advanced the discussion about this important concept. However, their general approach has been to use historical spreads against T's (or better yet, mathematical models without runs on hard data) to prove risk premiums at the long end (or small spreads at the short end) as evidence for their beliefs in preferred habitats.

All the empirical studies cited in the literature review undoubtedly advanced the discussion about this important concept of PHT, characterizing the behavior of bond yields. However, their general approach has been to use historical spreads against T's (or better yet, mathematical models without runs on hard data) to prove risk premiums at the long end (or small spreads at the short end) as evidence for their beliefs in preferred habitats. The US Treasury yield curve flattened considerably in 2017, reducing the spread between ten-year and two-year US Treasury yields to less than 60 basis points (Figure 1). When Alan Greenspan first referred to a bond market "conundrum" in 2005, the spread was around 80 basis points (Coeure, B, January 31, 2018)

\section{Materials and Methods}

This is a qualitative research using the interview method to collect data from a highly focused group consisting of bond traders and compliance officers by private U.S financial institutions of varying sizes with the help of a questionnaire for self-guidance with a sample size of 20 . This is ideal for research that entails interviews and a focused group of people in this study, as suggested by Creswell (Creswell \& Poth, 2018). Hence our study with a sample size of 20 using interview methodology is acceptable. Frequencies and simple percentages were used to analyze data.

It took many months of work to extract 20 responses. US Government bond traders usually monitor up to eight screens simultaneously while on the job. Their attention span for written documents on which money can't be made is best measured in nanoseconds. Therefore, the design of the questionnaire mandated that it be short and highly directed. The questionnaire is presented in Appendix A.

\section{Why Primary Data?}

Our collective real world experience led us to realize that using backward-viewed, secondary data to justify an ex-post theory was analogous to concluding that adult males wearing white shirts, dark suits, black hats and beards are without a doubt Amish. Higher rates at the back 
end are not prima facie proofs of market segmentation. It became important for us to use primary data to be able to test the contemporary validity of PHT.

After the data was collected, the responses were entered and cross-tabulated using SPSS, an analytical tool well known to social science researchers. Our cross-tabulations expressed as percentages are presented in Appendix B.

\section{Findings}

When trading strategy (question \#1) was tabulated against maturity preferences for buy and hold investors (question \#7), 55\% of the respondents stated that they had no preferences on the yield curve, supporting hypothesis \#1 meaning that that they do not have maturity preference in their strategy to buy or hold the securities. The implication is that the strategy for short- term or long-term depends on their individual economic conditions and overall market conditions. This is not in consistent with preferred habitat theory.

When we compared trading strategy (question \#1) with maturity preferences when trading in and out of Treasuries (question \#8), 45\% of the respondents stated that they had no preferences on the yield curve. Only $20 \%$ restricted their activities to the front-end of the curve. Therefore our hypothesis \#2 is supported, meaning that the investors did not have maturity preference for long term over short-term (only 5\% preferred for longer-term bond of 10 years and less, as seen in cross-tabulation \#2). The implication is that the investors will not tend to prefer to hold for long term over shorter-term if a higher return is not promised.

When arbitrage frequency (question \#3) was cross-tabulated against maturity preferences for buy and hold (question \#7), 50\% of the respondents stated that it is never a consideration. When question \#3 was cross-tabulated against question \#8, only $10 \%$ stated that they tried to stay on the short end, but $65 \%$ stated that they never considered having a preferred habitat when trading in or out. Hypotheses \#3 and 4 are thus supported.

When considering the identity of an arbitrage counterparty (question \#4) with maturity preferences for buy and hold (question \#7) and trading in and out (question \#8), half of the respondents in each case said that they don't even know if they have a preferred maturity on the yield curve, supporting again hypotheses \# 1 and 3.

When asked if the Dodd-Frank legislation had caused their trading practices to change. Surprisingly, everyone answered - and 70\% responded affirmatively, rejecting hypothesis \#5. This is obvious since the investors become subject to regulations in their trading practices and capital become restricted. Capital restrictions did appear to affect trading strategies. However, $25 \%$ of the respondents refused to answer this question. For those that did, $56 \%$ responded that capital restrictions did influence their preferred location of the yield curve, while $44 \%$ said that it did not - both for buy and hold investors as well as situational traders.

An inability to get a $100 \%$ response was also true for the last two cross-correlations. Where the managers had full trading discretion, $65 \%$ of the respondents (out of a total sample of 17) said that they had no maturity preferences for either buy-and-hold clients or for situational trade, thus supporting hypothesis \#1 and 2. 
We then analyzed spreads between various US Treasury obligations looking backwards from the present to different times during the Great Recession and our recovery from it. As is shown in Appendix C, spreads between short- and long-term debt are very small and getting smaller. Prior to the Great Recession, it was not unusual to see spreads of 350-450 basis points between three month and 30 year bonds. The contemporary data shows spreads of about 140 basis points on T-bonds covering the same horizon, and spreads of about 45 basis points between five and 30 year TIPs (“Treasury Inflation Protected Securities").

\section{Analysis}

Our study and sample size consisted of a focused group of small number of bond traders and compliance officers. Their responses and the published data on spreads strongly question whether PHT is still as widespread as generations of finance textbooks would imply. If these traders and compliance officers behaved properly, then one should have expected strong support for specific maturity ranges - both for buy and hold investors as well as for arbitrageurs. Yet most responses indicated that the ability (or need) to profit took preference over dogma. For most correlations, $50 \%$ or more of the respondents indicated that they had no preferred habitat at all, in spite of trading strategies impacted by the regulations of Dodd-Frank.

Bond rates have been very low since the Federal Reserve instituted the Quantitative Easing programs at the beginning of the Great Recession. Though said programs have now been discontinued, most Treasuries are still yielding less than the underlying inflation rate. Presumably, the need to justify their high compensation is forcing traders to bravely explore new worlds, horizons, and hedges where previous generation(s) of traders would not have wandered. The inability to find profitable arbitrage situations in a preferred habitat may be compelling institutions to venture outside of their historical comfort zones. It may also be contributing to the continued flattening of the curve, as the exploitation of trading anomalies wherever they may be found weaken the validity of market segmentation theory.

Clearly, the questionnaire should be repeated at some time in the future when both the absolute Treasury rates and spreads have increased. If those future responses were to show buyers and traders both gravitating to more traditional safe havens, the responses received in this study might be explained due to the persistent low yield environment. Alternatively, we might have to consider re-defining preferred maturities. Rather than teaching that certain classes of investors prefer a particular habitat, we might have to start looking at duration, rather than maturity, as the driver of bond trading strategies. We acknowledge that today's traders are probably compelled to look at pricing anomalies all over the yield curve in the pursuit of profit.

The absolute size of the Treasury market may also have an effect on the way the market participants react. The total amount of publicly traded US government debt was $\$ 274,374$ billion in 1955 (U.S. Department of the Treasury, Bureau of the Fiscal Service, 2013) and had swelled to a projected $\$ 20,492$ trillion (op.cit.) in 2017 . With so much paper that must constantly be refinanced in addition to new debt needed, it becomes increasingly difficult to arbitrage solely on the front end because of the humongous amounts of inventory, and the 
presence of huge central banks and sovereign wealth funds that didn't even exist in 1955 who now participate in the market as buyers. Although the dollar amount of most T-transactions is so large that humans still structure and book them, it is probably inevitable that program trading - now so prevalent in the equities markets - will take its place as a viable, reliable tool in the debt markets in years to come.

\section{Conclusion and Recommendation (s) for Future Research}

We have shown that the majority of our sample sophisticated bond buyers and traders do business in a way that challenges the traditional concept of preferred habitats on the yield curve. In the course of our research the subject of the traditional use of maturity in analyzing yield curve theories has come into question, and left us with an intriguing topic for future research, to wit: Has Duration replaced Maturity?

Additional investigation will be required to determine whether the underlying concept taught for over a half-decade might still be operative in a different environment, or whether changing economic conditions have caused the concept to have become obsolete. It also remains to be seen whether program trading - when it becomes commonplace to government bonds - will validate or reject the theory of preferred habitats.

\section{Acknowledgement}

We thank our colleagues at Touro College, Dr. Louis H. Primavera, Dean of the School of Health Sciences, Dr. Barry Bressler, Dean of Undergraduate Business Education, and Dr. Michael Szenberg, Chair and Distinguished Professor of Business and Economics, for their worthwhile suggestions in reviewing and making this paper both more readable and more substantive. Any remaining errors are attributed only to the authors.

\section{References}

Albuquerque, F. (2017). Term Spreads and Investors' Preferred Habitats in the US Treasury Yield Curve. Southwestern Finance Association. University of London. Retrieved from https://editorialexpress.com/cgi-bin/conference/download.cgi?db_name=SWFA2017\&paper_ $\mathrm{id}=16$

Coeure, B. (January 31, 2018). What yield curves are telling us. Financial Times European Financial Forum "Building a New Future for International Financial Services. Ireland, Dublin. Retrieved from https://www.bis.org/review/r180201b.pdf

Cox, J. C., Ingersoll, J., \& Ross, S. (1985). A Theory of the Term Structure of Interest Rates. Econometrica, 385-408. https://doi.org/10.2307/1911242

Creswell, J. W., \& Poth, C. N. (2018). Qualitative Inquiry \& Research Design: Choosimg among five approaches. Los Angeles: Sage.

Culbertson, J. (1957). The Term Structure of Interest Rates. The Quarterly Journal of Economics, 485-517. https://doi.org/10.2307/1885708

Ellison, M., \& Tischbirek, A. (2014). Unconventional government debt purchases as a 
supplement to conventional monetary policy. Journal of Economic Dynamics and Control, 199-217. https://doi.org/10.1016/j.jedc.2014.03.012

Elton, J. E., Brown, S. J., \& Goetzman, W. N. (2003). Modern Portfolio Theory and Investment Analysis. New York: John Wiley \& Sons.

Gorodnickenko, Y., \& Ray, W. (2017). The Effects of Quantitative Easing: Taking a Cue from Treasury Auctions. NBER Working Papers 24122, National Bureau of Economic Research, Inc. https://doi.org/10.3386/w24122

Greenwood, R., \& Vayanos, D. (2010). Price pressure in the government bond market. American Economic Review, 585-590. https://doi.org/10.1257/aer.100.2.585

Greenwood, R., Hanson, S., \& Stein, J. C. (2010). A Gap-Filling Theory of Corporate Debt Maturity Choice. Journal of Finance, 993-1028.

https://doi.org/10.1111/j.1540-6261.2010.01559.x

Guibaud, S., Nosbusch, Y., \& Vayanos, D. (2013). Bond Market Clienteles, the Yield Curve, and the Optimal Maturity Structure of Government Debt. Review of Financial Studies, Society for Financial Studies, 1914-1961. https://doi.org/10.1093/rfs/hht013

Hyoung-Seok, L. (2005). Estimation of the Term Structure of Interest Rates and its Featuures: Korea Case. Economic Analysis, 11(2).

Keynes, J. M. (1936). The General Theory of Employment, Interest and Money. London: Macmillan Cambridge University Press.

Krishnamurthy, A., \& Vissing-Jorgensen, A. (2012, April). The Aggregate Demand for Treasury Debt. Journal of Political Economy, 120(2). https://doi.org/10.1086/666526

Kuttner, K. N. (2006, August). can Central Banks Target Bond Prices? Retrieved april 18, 2018, from www.nber.org: http://www.nber.org/papers/w12454

Modigliani, F., \& Sutch, R. (1966). Innovations in Interest Rate Policy: Success and Failure. American Economic Review, 178-197.

Muth, J. F. (1961). Rational Expectations and the Theory of Price Movement. Econometrica, 315-335. https://doi.org/10.2307/1909635

Riedel, F. (2010, May 17). Heterogeneous time preferences and interest rates-the preferred habitat theory revisted. https://doi.org/10.1080/13518470210160885

U.S. Departement of the Treasury, Bureau of the Fiscal Service. (2017, December 31). The Daily History of Debt Results. Retrieved April 24, 2018, from Treasury Direct: https://www.treasurydirect.gov/NP/debt/search?startMonth=12\&startDay=31\&startYear=201 $7 \&$ endMonth $=\&$ endDay $=\&$ end Year $=$

U.S. Department of the Treasury, Bureau of the Fiscal Service. (2013, May 5). Historical Debt Outstanding - Annual 1950 - 1999. Retrieved April 24, 2018, from Treasury Direct: https://www.treasurydirect.gov/govt/reports/pd/histdebt/histdebt_histo4.htm 


\section{Macrothink}

Business and Economic Research

ISSN 2162-4860

2018, Vol. 8, No. 2

Vayanos, D. V., \& Vila ,Jean-Luc. (2009). A Preferred Habitat Model of the Term Structure of Interest Rates. NBER Working Papers, 15487. https://doi.org/10.3386/w15487

\section{Appendix 1}

Questionnaire

*1. How would you describe your primary US bond trading strategy?

Buy and hold

Spread trading

Sell side

*2. How would you describe your employer?

US financial institution

Foreign financial institution

*3. How often do you arbitrage different maturities of US government obligations?

Regularly

Often

Never

*4. If you engage in arbitrage, who are your counterparties (check all that might apply)?

US financial institution

Foreign financial institution

I don't know

5. Are there capital restrictions in place even in a very profitable arbitrage mis-pricing scenario?

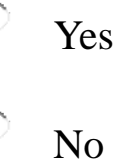

6. Do you have full discretion to trade in a very profitable arbitrage mispricing scenario?

$$
\begin{array}{c|c}
\text { Yes } \\
6 \text { No }
\end{array}
$$

*7. Do you have a preferred maturity on the yield curve when using a buy and hold strategy? 


\section{$0-1$ years \\ $1-3$ years \\ 3-5 years \\ 5-10 years \\ $>10$ years}

No preferences

*8. Do you have a preferred maturity on the yield curve when you trade in and out of treasuries?

$$
\begin{array}{l|l} 
& 0-1 \text { years } \\
& 1-3 \text { years } \\
3-5 \text { years } \\
5-10 \text { years } \\
\text { >10 years }
\end{array}
$$

No preferences

9. Have your trading practices changed since Dodd-Frank became effective?

True

False

\section{Appendix 2}

$$
\text { Survey Results (in percentages) }
$$

Cross-Tabulation \#1 - comparing trading strategy (question \#1) with maturity preferences for buy and hold (question \# 7)

\begin{tabular}{|l|l|l|l|}
\hline & Buy and hold & Spread trading & Sell side \\
\hline a. $0-1$ years & & 5 & \\
\hline b. $1-3$ years & & 5 & \\
\hline c. $3-5$ years & 5 & & 5 \\
\hline d. $5-10$ years & 5 & 10 & \\
\hline e. $>10$ years & 5 & & 5 \\
\hline
\end{tabular}




\begin{tabular}{|l|l|l|l|}
\hline f. no preferences & 35 & 10 & 10 \\
\hline Total 100 & 50 & 30 & 20 \\
\hline
\end{tabular}

Cross-Tabulation \#2 - comparing trading strategy (question \#1) with maturity preferences when trading in and out (question \# 8)

\begin{tabular}{|l|l|l|l|}
\hline & Buy and hold & Spread trading & Sell side \\
\hline a. 0-1 years & & & \\
\hline b. 1-3 years & & 10 & 10 \\
\hline c. 3-5 years & 5 & 5 & \\
\hline d. 5-10 years & 5 & & 10 \\
\hline e. $>10$ years & 5 & 5 & \\
\hline f. no preferences & 35 & 10 & \\
\hline Total 100 & 50 & 30 & 20 \\
\hline
\end{tabular}

Cross-Tabulation \#3 - comparing arbitrage frequency (question \#3) with maturity preferences for buy and hold (question \# 7)

\begin{tabular}{|l|l|l|l|}
\hline & Regularly & Often & Never \\
\hline a. 0-1 years & & 5 & \\
\hline b. 1-3 years & & 5 & \\
\hline c. 3-5 years & & & 10 \\
\hline d. 5-10 years & 10 & & 5 \\
\hline e. $>10$ years & 5 & & 5 \\
\hline f. no preferences & 5 & & 50 \\
\hline Total 100 & 20 & 10 & 70 \\
\hline
\end{tabular}

Cross-Tabulation \#4 - comparing arbitrage frequency (question \#3) with maturity preferences when trading in and out (question \# 8)

\begin{tabular}{|l|l|l|l|}
\hline & Regularly & Often & Never \\
\hline a. 0 -1 years & & 5 & \\
\hline b. 1-3 years & 5 & 5 & 10 \\
\hline c. 3-5 years & & & 5 \\
\hline d. 5-10 years & 10 & & 10 \\
\hline e. >10 years & 5 & & \\
\hline f. no preferences & 5 & & 40 \\
\hline Total 100 & 25 & 10 & 65 \\
\hline
\end{tabular}

Cross-Tabulation \#5 - comparing arbitrage counterparties (question \#4) with maturity preferences for buy and hold (question \# 7)

\begin{tabular}{|l|l|l|}
\hline & U.S. & Foreign Don't Know \\
\hline a. $0-1$ years & 5 & \\
\hline b. 1-3 years & 5 & \\
\hline c. 3-5 years & 5 & 5 \\
\hline
\end{tabular}




\begin{tabular}{|l|l|l|}
\hline d. $5-10$ years & 10 & 5 \\
\hline e. $>10$ years & 5 & 5 \\
\hline f. no preferences & 20 & 35 \\
\hline Total 100 & 50 & 20 \\
\hline
\end{tabular}

Cross-Tabulation \#6 - comparing arbitrage counterparties (question \#4) with maturity preferences when trading in and out (question \# 8)

\begin{tabular}{|l|l|l|}
\hline & U.S. & Foreign Don't Know \\
\hline a. 0-1 years & & \\
\hline b. 1-3 years & 20 & \\
\hline c. 3-5 years & 5 & 5 \\
\hline d. 5-10 years & 5 & 10 \\
\hline e. $>10$ years & 10 & \\
\hline f. no preferences & 10 & 35 \\
\hline Total 100 & 50 & 50 \\
\hline
\end{tabular}

Cross-Tabulation \#7 - comparing capital restrictions (question \#5) with maturity preferences for buy and hold (question \# 7)

\begin{tabular}{|l|l|l|}
\hline & Yes & No \\
\hline a. 0-1 years & 5 & \\
\hline b. 1-3 years & & 5 \\
\hline c. 3-5 years & 5 & \\
\hline d. 5-10 years & 10 & 5 \\
\hline e. $>10$ years & 5 & \\
\hline f. no preferences & 20 & 25 \\
\hline Total 80 & 45 & 35 \\
\hline
\end{tabular}

Cross-Tabulation \#8 - comparing capital restrictions (question \#5) with maturity preferences when trading in and out (question \# 8)

\begin{tabular}{|l|l|l|}
\hline & Yes & No \\
\hline a. $0-1$ years & & \\
\hline b. 1-3 years & 10 & 5 \\
\hline c. 3-5 years & 5 & \\
\hline d. 5 -10 years & 5 & 5 \\
\hline e. $>10$ years & 10 & \\
\hline f. no preferences & 15 & 20 \\
\hline Total 80 & 45 & 35 \\
\hline
\end{tabular}

Cross-Tabulation \#9 - comparing Full Discretion (question \#6) with maturity preferences for buy and hold (question \# 7)

\begin{tabular}{|l|l|l|}
\hline & Yes & No \\
\hline a. $0-1$ years & 5 & \\
\hline
\end{tabular}




\begin{tabular}{|l|l|l|}
\hline b. 1-3 years & & 5 \\
\hline c. 3-5 years & 10 & \\
\hline d. 5-10 years & & 15 \\
\hline e. $>10$ years & & 5 \\
\hline f. no preferences & 15 & 30 \\
\hline Total 85 & 30 & 55 \\
\hline
\end{tabular}

Cross-Tabulation \#10 - comparing Full Discretion (question \#6) with maturity preferences when trading in and out (question \# 8)

\begin{tabular}{|l|l|l|}
\hline & Yes & No \\
\hline a. $0-1$ years & & \\
\hline b. 1-3 years & 5 & 10 \\
\hline c. 3-5 years & 10 & \\
\hline d. $5-10$ years & 5 & 5 \\
\hline e. $>10$ years & & 10 \\
\hline f. no preferences & 10 & 30 \\
\hline Total 85 & 30 & 55 \\
\hline
\end{tabular}

Question 9 (no cross-tabulations) - Dodd-Frank impact on trading

Yes -70

No -30

\section{Appendix 3}

BACKWARD VIEW OF SPREADS OF DIFFERENT COMBINATIONS OF TREASURY INSTRUMENTS

\begin{tabular}{|l|l|l|l|l|l|l|}
\hline & & $30-10 \mathrm{yr}$ & & $30-2 \mathrm{yr}$ & & 2 yr- 2 yr fltr \\
\hline $10 / 12 / 2017$ & $10 / 11 / 2017$ & $0.52 \%$ & $9 / 26 / 2017$ & $1.41 \%$ & $9 / 27 / 2017$ & $1.407 \%$ \\
\hline $9 / 13 / 2017$ & $9 / 12 / 2017$ & $0.61 \%$ & $8 / 28 / 2017$ & $1.45 \%$ & $8 / 23 / 2017$ & $1.285 \%$ \\
\hline $8 / 10 / 2017$ & $8 / 9 / 2017$ & $0.57 \%$ & $7 / 25 / 2017$ & $1.42 \%$ & $7 / 26 / 2017$ & $1.335 \%$ \\
\hline $7 / 13 / 2017$ & $7 / 12 / 2017$ & $0.61 \%$ & $6 / 26 / 2017$ & $1.59 \%$ & $6 / 28 / 2017$ & $1.268 \%$ \\
\hline $6 / 13 / 2017$ & $6 / 12 / 2017$ & $0.68 \%$ & $5 / 23 / 2017$ & $1.55 \%$ & $5 / 24 / 2017$ & $1.266 \%$ \\
\hline $5 / 11 / 2017$ & $5 / 10 / 2017$ & $0.65 \%$ & $4 / 25 / 2017$ & $1.77 \%$ & $4 / 26 / 2017$ & $1.210 \%$ \\
\hline $4 / 12 / 2017$ & $4 / 11 / 2017$ & $0.61 \%$ & $3 / 27 / 2017$ & $1.68 \%$ & $3 / 29 / 2017$ & $1.152 \%$ \\
\hline $3 / 9 / 2017$ & $3 / 8 / 2017$ & $0.61 \%$ & $2 / 21 / 2017$ & $1.94 \%$ & $2 / 22 / 2017$ & $1.097 \%$ \\
\hline $2 / 9 / 2017$ & $2 / 8 / 2017$ & $0.67 \%$ & $1 / 24 / 2017$ & $1.80 \%$ & $1 / 25 / 2017$ & $1.070 \%$ \\
\hline
\end{tabular}

\begin{tabular}{|l|l|l|l|l|l|}
\hline & \multicolumn{2}{|l|}{$30 \mathrm{yr}-30 \mathrm{yr}$ floater } & & \multicolumn{2}{l|}{$10 \mathrm{yr}-10 \mathrm{yr}$ floater } \\
\hline $10 / 19 / 2017$ & $1.96 \%$ & & $9 / 21 / 2017$ & $1.73 \%$ & \\
\hline $6 / 22 / 2017$ & $1.99 \%$ & & $7 / 20 / 2017$ & $1.84 \%$ & \\
\hline $2 / 16 / 2017$ & $2.08 \%$ & & $5 / 18 / 2017$ & $1.98 \%$ & \\
\hline & & & $3 / 23 / 2017$ & $2.09 \%$ & \\
\hline
\end{tabular}




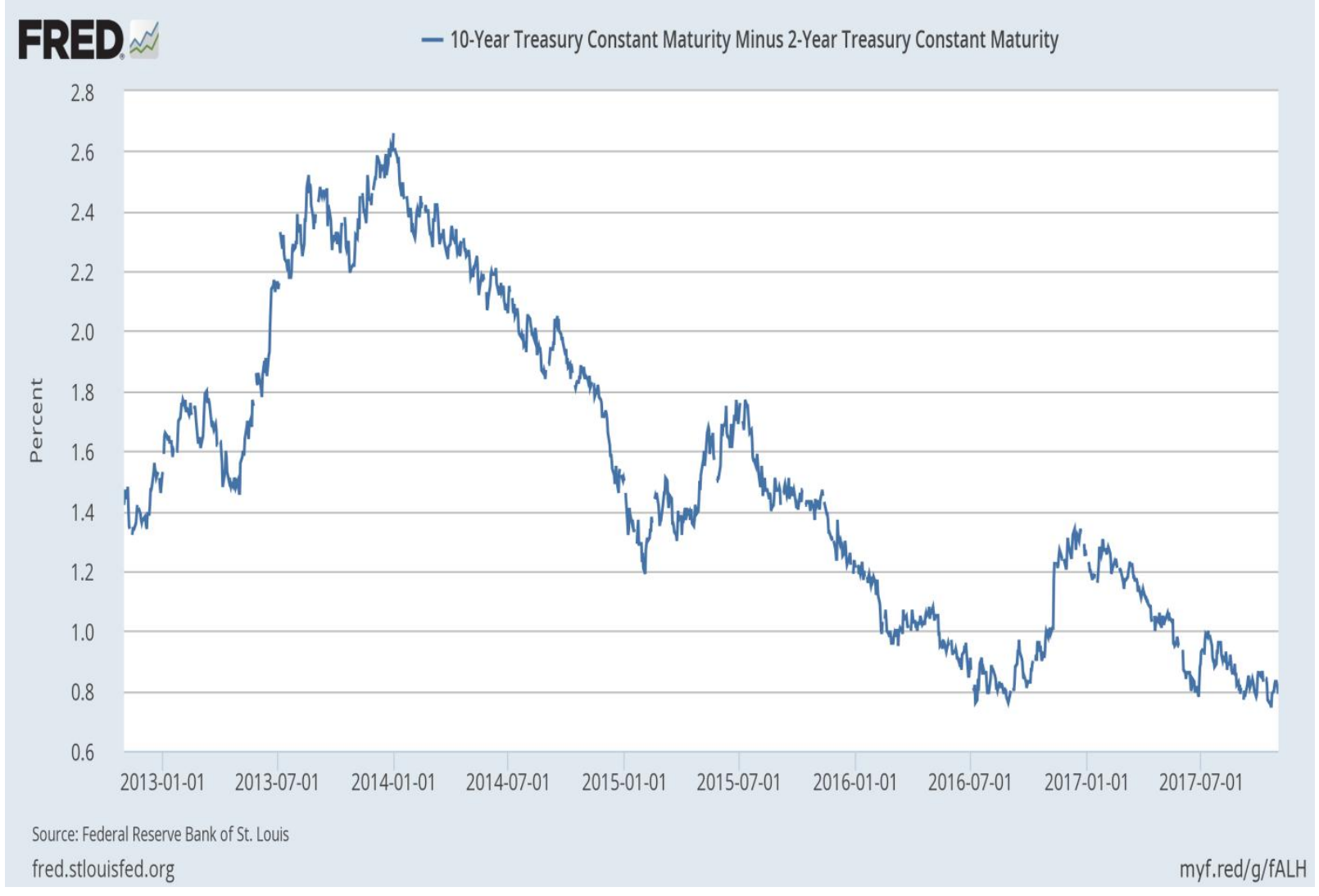

Figure 1.

\section{Copyright Disclaimer}

Copyright for this article is retained by the author(s), with first publication rights granted to the journal.

This is an open-access article distributed under the terms and conditions of the Creative Commons Attribution license (http://creativecommons.org/licenses/by/3.0/). 